\title{
Scientific Libraries Examined
}

\author{
A recent report from the Library Association urges changes in the \\ organization of libraries in Britain.
}

LIBRARIEs in Britain have attracted considerable attention in recent weeks-the problems of the British Museum have made sure of that. The report of a committee of the Library Association on scientific libraries (Scientific Library Services, Library Association, 16s.) is unlikely to stir up public interest in quite the same way but it is none the less important for that.

To quote the report, "Government departments, universities, colleges, research establishments and industries which have readily recognized the need for rapid expansion of their scientific or technological branches have often failed to appreciate the need for the same dynamic policy in their libraries. Even where library development of this kind is acknowledged to be necessary, it is hampered by the very great shortage of librarians trained in one or other of the sciences'". The report is apparently the first comprehensive attempt to review the problem of British scientific library services as a whole. It is a result of a study made by a special independent committee set up by the Library Association in 1964, under the chairmanship of Major-General C. Lloyd. The committee set out to review the provision of specialist library services not merely for scientists and technologists but for other specialist worknrs in government departments, public authorities, universities, colleges, research establishments and industry.

At the local level, the report says, "there exists among scientists and technologists a large degree of ignorance of the availability of library and information services. Many are not even familiar with the serviees and journals available within their own particular field..." The committec is disturbed about this lack of exploitation of the literature which is, or could be, available at local level and at the apathy towards local library and literature information services. It complains that people rely too much on specialist services provided by research associations and learned societies which are usually available from only one national centre which is "geographically remote from the majority of mcmbers". To correct this situation the committee urges that more specialist library and information workers should be provided at the local level and that the local library authority be given a statutory responsibility for developing suitable services.

Wherever possible, university libraries should be incorporated into the national scientific and technical library services. One recommendation which should be relatively easy to put into practice is that which would allow members of one library free use of related librarics on a reciprocal basis which would do away with delaying procedures such as written applications and letters of introduction. Many publio libraries, after all, have introduced inter-availability of tickets.

On a national level, the committee makes a com. parison of the services provided by the National Lending Library, the Patent Office Library, the new Reference Librury for Seience and Invention and the
National Central Library on the one hand with the services of the large state libraries of the Soviet Union and the All-Union Institute of Scientific and Technical Information (VINITI) on the other. 'The committee adds its plea to all the others made in the past few years, that there should be no more delay in the full operation of the National Reference Library. It also recommends that this library should be given the task of developing a National Co-ordinating and Referral Centre to "back up" and co-ordinate the specialized and local centres. Aslib's national referral organization, operating through the Aslib Information Department and the Aslib Directory of sources of information, could possibly provide the referral services for this centre. This would mean finding room for Aslib on the same site as the National Reference Jibrary-a thought for the Dainton committee.

The committee has drawn up a table with its recommendations on the structure of scientific and technical library and information services at local, regional and national levels. It believes the aim should be that any organization needing scientitic and technical documents and information should be able to satisfy at least half of its nceds within its locality (half an hour's travelling each way); eighty per cent within the region (two hours each way); and virtually all its needs within Great Britain. Central finance should be made available to enable libraries to provide a more efficient service, and the Department of Education and Science should "treat the co-ordinated development of information services as of national importance and urgency", now that it has wide powers in library mattcrs.

It goes without saying that specialist library staff are a necessary adjunct to the provision of efficient scientific and technical library services. The committee makes several recommendations, some of which are in fact already receiving attention. Soon after its establishment the committee asked the Library Association to devise some means for the formal education and admission to the register of scientists of a "mature" age. It was pointed out that of approximately 1,000 scientists engaged in library and information work, only 3 per cent werc on the register of chartered librarians, and that it was impossible for most of them to study full-time and so obtain formal qualification. Accordingly, the association devised a scheme for mature graduate entrants.

One way and another, the report covers a lot of ground; it uncovers many inadequacies of the present situation, although it is doubtful when any of the recommendations will be put into practice. Major changes are of course affected by the economic situation, like everything else, and there is also uncertainty about what the Dainton committee will say. It is to be noted that the views expressed in the report are those of the Scientific Libraries Committee and not necessarily those of the Library Association. The association itself is in the middle of detailing a lengthy memorandum to the Dainton committee. 